\title{
Economic viability of lettuce (Lactuca sativa, L.) grown in hydroponic system with different optimized nutrient solutions
}

\author{
Antonio Fernandes Monteiro Filho ${ }^{1}$, Carlos Alberto Vieira de Azevedo ${ }^{2 *, 4}$, Márcia Rejane de Queiroz \\ Almeida Azevedo ${ }^{1}$, Josely Dantas Fernandes ${ }^{1}$, Severina de Sousa ${ }^{3}$, Pedro Dantas Fernandes ${ }^{2,5}$ \\ ${ }^{1}$ State University of Paraíba, Center of Environmental and Agrarian Sciences, Lagoa Seca, 58.117-000, Paraíba, Brazil \\ ${ }^{2}$ Federal University of Campina Grande, Academic Unit of Agricultural Engineering, Campina Grande, 58.429-140, \\ Paraíba, Brazil \\ ${ }^{3}$ Federal University of Campina Grande, Academic Unit of Food Engineering, Campina Grande, 58.429-140, Paraíba, \\ Brazil \\ ${ }^{4}$ Fellow of CNPq Research Productivity, level 1B, Brazil \\ ${ }^{5}$ Fellow of CNPq Research Productivity, level 1A, Brazil
}

*Corresponding author: cvieiradeazevedo@gmail.com

Abstract

Hydroponic cultivation is characterized by high initial costs compared with conventional cultivation. This study discusses the economic viability of implementing a hydroponic system for lettuce production with different mineral and organomineral nutrient solutions through simulation. The experimental design was randomized blocks with split plots and three replicates. Plots consisted of eight nutrient solutions: four mineral solutions, with chemical compositions proposed by Bernardes, Castellane and Araújo, Furlani, and Ueda, and four solutions with chemical compositions similar to those previously cited, but modified in the present research with the utilization of biofertilizer in the composition, to produce four organomineral nutrient solutions. Subplots consisted of three varieties of curly lettuce: Verônica, Vanda and Thaís. After harvesting, lettuce plants were separately weighed according to the treatments and, from this information, the selling price was determined based on research conducted in major supermarkets in the city of Campina Grande, Paraíba, Brazil. The calculation of expenses took into account the effective operating cost, total operating costs and the total production cost. According to the simulation, regardless of the cultivar used, lettuce hydroponic cultivation had higher annual profit, with values of US\$18,880.00 and 18,730.00, using the mineral nutrient solutions of Furlani and Bernardes, respectively. Among the organomineral nutrient solutions, the Furlani solution when used in the production of the cultivar Verônica led to annual profit of US\$11,440.00.

Keywords: Lactuca sativa, L., hydroponics, profitability, simulation.

Abbreviations: BM_mineral nutrient solution of Bernardes (1997); FM_mineral nutrient solution of Furlani (1995); CM_mineral nutrient solution of Castellane and Araújo (1994); UM_mineral nutrient solution of Ueda (1990); BO_modified nutrient solution of Bernardes (1997); FO_modified nutrient solution of Furlani (1995); CO_modified nutrient solution of Castellane and Araújo (1994); UO_modified nutrient solution of Ueda (1990); BIO1_Biofertilizer used in the modified solution of Ueda (1990); BIO2_Biofertilizer used in the modified solution of Castellane and Araújo (1994); BIO3_Biofertilizer used in the modified solution of Furlani (1995); BIO4_Biofertilizer used in the modified solution of Bernardes (1997): TH_Cultivar Thaís; VA_Cultivar Vanda; VE_Cultivar Verônica; EOC_Effective operating cost; TOC_Total operating cost; TPC_Total production cost; CRSS_Contribution to rural social security; PI_Profitability Index; OP_Operating profit; GR_Gross Revenue.

\section{Introduction}

The search for high-quality healthy diet has become an increasingly practiced habit, which points to the progressive consumption of leafy vegetables (Borges and Dal'Sotto, 2014). In this group, lettuce is the most produced and consumed leafy vegetable (Costa and Sala, 2012; Hens and Suinaga, 2009). In Brazil, more than 66,000 rural properties produce commercial lettuce and the main producing regions are: Southeast $(30 \%)$, South $(30 \%)$, Northeast $(26 \%)$, Midwest (7\%) and North (6\%) (IBGE, 2009).
Production seasonality, climatic variations and the scarcity of land as a production factor are, among others, peculiar characteristics of the agricultural sector that can reduce food production and increase the risks of rural activities. Given these limiting factors, the technique of hydroponics stands out for having, compared with the conventional system, higher yield, less labor and area, besides saving water, factors that are necessary for the increase in the 
regularity of vegetable production (Villela Júnior et al., 2004; Andriolo et al., 2005).

In Brazil, the commercial cultivation of vegetables and ornamental plants using hydroponic techniques has rapidly increased close to the large urban centers, in which the arable lands are scarce and expensive, with great demand for vegetable products. In these regions, vegetables are mostly produced in protected cultivation, a situation in which the hydroponic system presents itself as an advantageous alternative (Martinez and Silva Filho, 2006).

According to Soares (2002), lettuce cultivation in Brazil corresponds to $90 \%$ of the total produced using hydroponics, which emphasizes the importance of economic studies for this crop and cultivation system, allowing a greater scientific support and safety for the farmers.

One of the main concerns of vegetable producers with respect to hydroponic cultivation is related to the high initial cost of production, requiring land leveling, construction of greenhouses, tables, benches and hydraulic and electric systems. However, according to Santos et al. (2008), the hydroponic cultivation of lettuce has economic viability when the crop is grown with mineral solutions, but there is no formulation considered as ideal, because it involves a large number of variables and their interactions (Rodrigues, 2002). The solution of Furlani (1995) is the most used and little is known about the utilization of organomineral solutions.

The technique of hydroponics is still little used in the Northeast region of Brazil, and one of the reasons may be associated with the lack of information on the economic viability of the cultivation of vegetables. Therefore, this study aimed to analyze the economic viability of curly lettuce hydroponic cultivation using mineral and organomineral nutrient solutions.

\section{Results and discussion}

\section{Production costs}

The worksheets of implementation cost (operation and consumables), effective operating cost (EOC), total operating cost (TOC) and total production cost (TPC) of hydroponic lettuce, are detailed in Table 1.

According to Table 1, the utilization of modified solutions, in comparison to the mineral solutions with the same composition, reduced the effective operating cost (EOC) by $1.94,3.05,0.00$ and $1.26 \%$ for the modified solutions of Furlani (1995) (FO), Bernardes (1997) (BO), Ueda (1990) (UO) and Castellane and Araújo (1994) (CO), respectively. The partial substitution of chemical fertilizers by the biofertilizer in the preparation of the modified solutions justifies this result, corroborating Resende et al. (2007). Cometi et al. (2008), working with the effect of the nutritious concentration on hydroponic lettuce growth, concluded that the utilization of less concentrated solutions and, consequently, with lower amount of fertilizers, reduces the production cost without altering crop yield.

Using the biofertilizer to prepare the nutrient solution is important because it has diversified chemical composition in macro- and micronutrients and, additionally, its manufacture may have reduced cost, since most farmers already have the organic ingredients used in its formulation and/or can include other ingredients available in the property, at a reduced cost, which will decrease even more the expenditures of the producer (Fernandes et al., 2011). Still according to Table 1, EOC represented on average $48.9 \%$ of the total production cost (TPC) and the payment of greenhouse financing was the item that would have highest impact, corresponding to $45 \%$ of the EOC. According to Silva and Schwonka (2001), the highest costs to implement the hydroponic system are related to the acquisition of the greenhouse and equipment.

The total operating cost (TOC) increased in relation to the effective operating cost (EOC) by 101.70, 101.95, 100.12, $99.43,100.82,99.05,100.30$ and $99.61 \%$, using the solutions $\mathrm{FM}, \mathrm{FO}, \mathrm{BM}, \mathrm{BO}, \mathrm{UM}, \mathrm{UO}, \mathrm{CM}$ and $\mathrm{CO}$, respectively. This increment came from the expenditures with business remuneration, social charges and Special Contribution to Rural Social Security (CRSS), considering the entire annual production. The small oscillations observed between the percent increments were due to the CRSS, because this contribution is calculated based on the gross revenue of the enterprise.

It is indispensable to point out that the business remuneration during the production process corresponded, on average, to $40.38 \%$ of the TOC. This value stands out because of its importance, since it guarantees a monthly income to the farmer during the production process, even without counting the profits from the production.

Finally, the TPC was determined by summing the total operating cost and the expenditure of the land lease, which was estimated as $R \$ 1,300.00$ year $^{-1}$; this is the mean value charged by the lease of 1 ha in the farms located in the municipality of Lagoa Seca, Paraíba. TPC reached values of US\$20,579.48, 20,213.91, 20,737.45, 20,049.18, 19,912.92, $19,741.08,20,348.84$ and $20,031.28$ for lettuce plants cultivated with the solutions FM, FO, BM, BO, UM, UO, CM and $\mathrm{CO}$, respectively (Table 1 ).

In this simulation, from the sixth year of implementation on, the total production costs showed a sharp decrease due to the financing pay off to install the project. This reduction would represent, in percent terms, decreases of 23.39, 21.78, 21.23, 21.96, 22.10, 22.30, 21.63 and $21.98 \%$ using the solutions FM, FO, BM, BO, UM, UO, CM and $\mathrm{CO}$, respectively. This cost reduction would have a significant impact on the decrease in the unit cost per plant, changing from US\$ 0.206, 0.203, 0.200, 0.200, 0.197, 0.197, 0.203 and 0.200 to $\mathrm{R} \$ 0.163,0.159,0.163,0.156,0.156,0.153,0.159$ and 0.156 using the solutions FM, FO, BM, BO, UM, UO, CM and $\mathrm{CO}$, respectively.

\section{Production profitability}

Based on the profitability indicators obtained for the different cultivars and nutrient solutions described in Table 2, the cultivars Verônica, Vanda and Thaís showed the highest gross revenue (GR) with the utilization of the mineral solutions FM and BM, with revenue of US\$39,062.50 year ${ }^{-1}$. Regarding the use of modified nutrient solutions, the highest revenue was obtained in the cultivation of Verônica lettuce in the solution FO, reaching value of US\$ 31,250.00 year ${ }^{-1}$. In the investment analysis, a minimum attractive rate of return must be stipulated as basis for the calculations of viability; this is an interest rate that represents the minimum an investor intends to earn when she/he makes an investment. Borges and Dal'Sotto (2014), evaluating the 
Table 1. Unit values of the items used in the production cost of hydroponic lettuce as a function of the different nutrient solutions.

\begin{tabular}{|c|c|c|c|c|c|c|c|c|}
\hline \multirow{3}{*}{ Fixed Cost $(A)$} & \multicolumn{8}{|c|}{ Nutrient solutions } \\
\hline & FM & FO & BM & $\mathrm{BO}$ & UM & UO & CM & $\mathrm{CO}$ \\
\hline & \multicolumn{8}{|c|}{ - Monetary value (US\$)-- } \\
\hline Greenhouse & $4,402.38$ & $4,402.38$ & $4,402.38$ & $4,402.38$ & $4,402.38$ & $4,402.38$ & $4,402.38$ & $4,402.38$ \\
\hline & \multicolumn{7}{|c|}{ Variable costs (B) } & $1,687.50$ \\
\hline Seeds & 253.12 & 253.12 & 253.12 & 253.12 & 253.12 & 253.12 & 253.12 & 253.12 \\
\hline Electric power & 468.75 & 468.75 & 468.75 & 468.75 & 468.75 & 468.75 & 468.75 & 468.75 \\
\hline Foam & 468.75 & 468.75 & 468.75 & 468.75 & 468.75 & 468.75 & 468.75 & 468.75 \\
\hline Maintenance & 750.00 & 750.00 & 750.00 & 750.00 & 750.00 & 750.00 & 750.00 & 750.00 \\
\hline Labor & $1,606.25$ & $1,606.25$ & $1,606.25$ & $1,606.25$ & $1,606.25$ & $1,606.25$ & $1,606.25$ & $1,606.25$ \\
\hline Nutrient solution & 366.27 & 172.58 & 254,24 & 214.10 & 77,84 & 77.86 & 321.26 & 196.19 \\
\hline $\mathrm{EOC}(\mathrm{A}+\mathrm{B})$ & $10,000.00$ & 9806.25 & $10,159.38$ & $9,850.00$ & $9,725.50$ & $9,725.50$ & $9,926.25$ & $9,831.25$ \\
\hline \multicolumn{9}{|l|}{$\begin{array}{l}\text { Other Operating Costs } \\
\text { (C) }\end{array}$} \\
\hline Social Charges & $1,156.25$ & $1,156.25$ & $1,156.25$ & $1,156.25$ & $1,156.25$ & $1,156.25$ & $1,156.25$ & $1,156.25$ \\
\hline CRSS & 859.38 & 687.50 & 859.38 & 481.25 & 481.25 & 309.38 & 673.75 & 481.25 \\
\hline Business remuneration & $8,156.25$ & $8,156.25$ & $8,156.25$ & $8,156.25$ & $8,156.25$ & $8,156.25$ & $8,156.25$ & $8,156.25$ \\
\hline $\mathrm{TOC}(\mathrm{EOC}+\mathrm{C})$ & $20,171.86$ & 19.806 .25 & $20,331.25$ & $19,743,00$ & $19,506.25$ & $19,334.36$ & $19,973.45$ & $19,625.00$ \\
\hline \multicolumn{9}{|l|}{ Other Fixed Costs (D) } \\
\hline Lease (F) & 406.25 & 406.25 & 406.25 & 406.25 & 406.25 & 406.25 & 406.25 & 406.25 \\
\hline$T P C(A+B+C+D+F)$ & $20,579,48$ & $20,213.91$ & $20,737.45$ & $20,049.18$ & 19,912. 92 & $19,741.08$ & $20,348.84$ & $20,031.28$ \\
\hline
\end{tabular}

CRSS - contribution to rural social security. FM, BM, UM and CM are the mineral solutions of Furlani (1995), Bernardes (1997), Ueda (1990) and Castellane and Araújo (1994), respectively; FO, BO, UO and CO are the modified solutions of Furlani (1995), Bernardes (1997), Ueda (1990), and Castellane and Araújo (1994), respectively.

Table 2. Profitability indices of curly lettuce cultivars as a function of the different nutrient solutions.

\begin{tabular}{|c|c|c|c|c|c|c|c|c|c|}
\hline & \multirow{2}{*}{ UNT } & \multicolumn{7}{|c|}{ Cultivar Verônica } & \multirow[b]{2}{*}{$\mathrm{CO}$} \\
\hline & & $\overline{F M}$ & FO & BM & $\mathrm{BO}$ & UM & UO & $\mathrm{CM}$ & \\
\hline GR & 1000 US\$ & 39.06 & 31.25 & 39.06 & 21.86 & 21.86 & 14.06 & 30.63 & 21.86 \\
\hline GMEOC & $\%$ & 290.57 & 218.62 & 284.49 & 122.10 & 125.21 & 44.78 & 207.59 & 122.50 \\
\hline GMTOC & $\%$ & 93.64 & 57.77 & 92.13 & 11.36 & 12.14 & -27.27 & 53.57 & 11.46 \\
\hline GMTPC & $\%$ & 89.81 & 54.60 & 88.37 & 9.11 & 9.85 & -28.77 & 50.50 & 9.20 \\
\hline BEPCOE & 1000 UNT & 25.67 & 31.38 & 26.00 & 45.02 & 44.40 & 69.07 & 32.51 & 44.94 \\
\hline BEPCOT & 1000 UNT & 51.64 & 63.38 & 52.47 & 89.79 & 89.17 & 13.74 & 65.11 & 89.71 \\
\hline BEPCTP & 1000 UNT & 52.68 & 64.68 & 53.08 & 91.65 & 91.03 & 140.38 & 66.44 & 91.57 \\
\hline OP & 1000 US\$ & 18.89 & 11.44 & 18.73 & 2.23 & 2.37 & -5.27 & 10.68 & 2.250 \\
\hline \multirow[t]{2}{*}{$\mathrm{PI}$} & $\%$ & 48.36 & 36.62 & 47.95 & 10.20 & 10.83 & -37.49 & 34.88 & 10.29 \\
\hline & \multicolumn{8}{|c|}{ Cultivar Vanda } & \\
\hline$\overline{G R}$ & 1000 US\$ & 39.06 & 21.86 & 39.06 & 21.86 & 30.63 & 14.06 & 30.63 & 14.06 \\
\hline GMEOC & $\%$ & 290.57 & 123.04 & 284.49 & 122.10 & 215.30 & 44.78 & 207.59 & 43.04 \\
\hline GMTOC & $\%$ & 93.64 & 10.44 & 92.13 & 11.36 & 57.00 & -27.27 & 53.57 & -28.34 \\
\hline GMTPC & $\%$ & 89.81 & 8.22 & 88.37 & 9.11 & 53.79 & -28.77 & 50.50 & -29.80 \\
\hline BEPCOE & 1000 UNT & 25.60 & 44.83 & 26.00 & 45.02 & 31.71 & 69.07 & 32.510 & 69.91 \\
\hline BEPCOT & 1000 UNT & 51.64 & 90.54 & 52.04 & 89.79 & 63.69 & 137.49 & 65.118 & 139.55 \\
\hline ВEPCTP & 1000 UNT & 52.68 & 92.40 & 53.08 & 91.65 & 65.02 & 140.38 & 66.44 & 142.44 \\
\hline OP & 1000 US\$ & 18.89 & 2.07 & 18.73 & 2.23 & 11.12 & -5.27 & 10.52 & -5.56 \\
\hline \multirow[t]{2}{*}{$\underline{\mathrm{PI}}$} & $\%$ & 48.36 & 9.45 & 47.95 & 10.20 & 36.30 & -37.49 & 34.88 & -39.56 \\
\hline & \multicolumn{8}{|c|}{ Cultivar Thaís } & \\
\hline$\overline{G R}$ & 1000 US\$ & 39.06 & 21.86 & 39.06 & 14.06 & 30.63 & 14.06 & 30.63 & 14.06 \\
\hline GMEOC & $\%$ & 290.57 & 123.04 & 284.49 & 296.60 & 302.17 & 302.16 & 292.33 & 297.32 \\
\hline GMTOC & $\%$ & 93.64 & 10.44 & 92.13 & -28.41 & 57.00 & -27.27 & 53.57 & -28.34 \\
\hline GMTPC & $\%$ & 89.81 & 6.30 & 89.81 & -31.67 & 48.81 & -31.67 & 48.81 & -31.67 \\
\hline BEPCOE & 1000 UNT & 25.60 & 44.83 & 26.08 & 45.025 & 31.71 & 69.07 & 32.51 & 69.91 \\
\hline BEPCOT & 1000 UNT & 51.64 & 90.54 & 52.04 & 139.68 & 63.69 & 137.49 & 65.11 & 139.55 \\
\hline ВEРCTP & 1000 UNT & 52.68 & 92.40 & 53.08 & 142.57 & 65.02 & 140.38 & 66.44 & 142.44 \\
\hline $\mathrm{OP}$ & 1000 US\$ & 18.88 & 20.67 & 18.73 & -5.58 & 11.12 & -5.27 & 10.68 & -5.56 \\
\hline $\mathrm{PI}$ & $\%$ & 48.36 & 9.45 & 47.95 & -39.68 & 36.30 & -37.49 & 34.88 & -39.56 \\
\hline
\end{tabular}

FM, BM, UM and CM are the mineral solutions of Furlani (1995), Bernardes (1997), Ueda (1990) and Castellane and Araújo (1994), respectively; FO, BO, UO and CO are the modified solutions of Furlani (1995), Bernardes (1997), Ueda (1990), and Castellane and Araújo (1994), respectively. 
Table 3. Profitability index of the cultivars Verônica, Vanda and Thaís produced in hydroponic system with different nutrient solutions after the fifth year of implementation of the activity.

\begin{tabular}{lllllllll}
\hline & \multicolumn{8}{c}{ Nutrient Solutions } \\
\cline { 2 - 6 } Cultivar & FM & FO & BM & BO & UM & UO & CM & CO \\
& Verônica & 59.63 & 50.70 & 59.22 & 30.33 & 30.95 & -6.19 & 49.26 \\
Vanda & 59.63 & 29.58 & 59.22 & 30.33 & 50.68 & -6.19 & 49.26 & -8.25 \\
Thaís & 59.63 & 49.58 & 59.22 & -8.38 & 50.68 & -6.19 & 49.26 & -8.25 \\
\hline
\end{tabular}

FM, BM, UM and CM are the mineral solutions of Furlani (1995), Bernardes (1997), Ueda (1990) and Castellane and Araújo (1994), respectively; FO, BO, UO and CO are the modified solutions of Furlani (1995), Bernardes (1997), Ueda (1990), and Castellane and Araújo (1994), respectively.

A
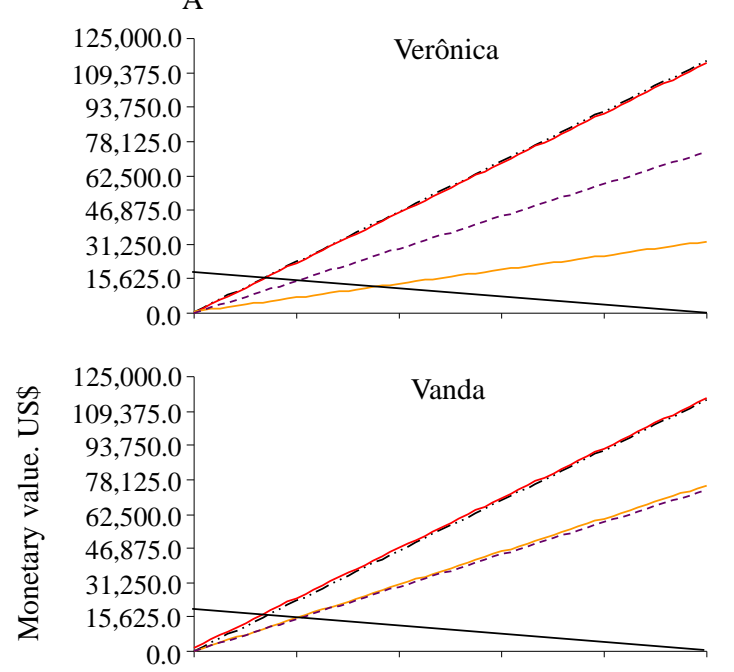

0.0

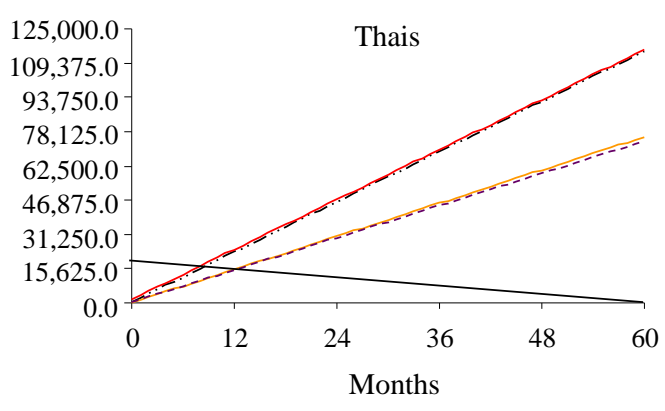

_ Financing balance due

$-\cdot-$ FM - BM - UM -.- $\mathrm{CM}$
$\mathrm{B}$
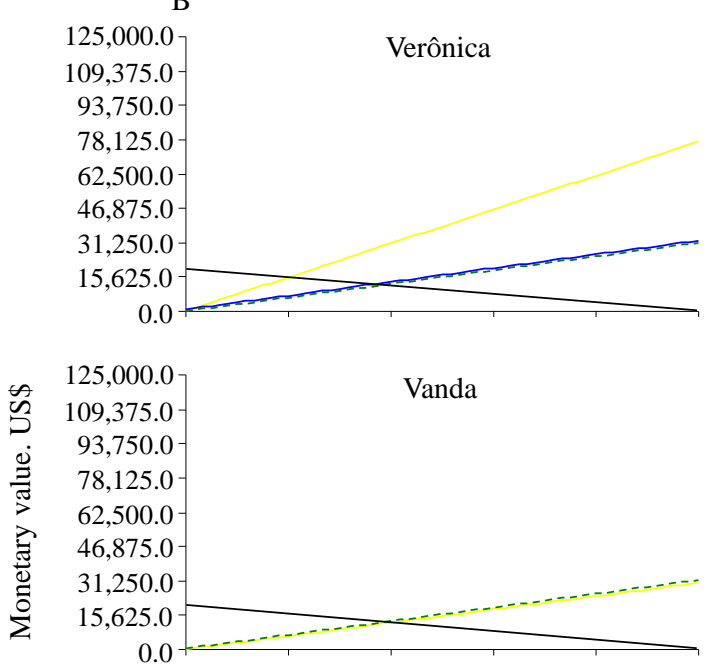

0.0

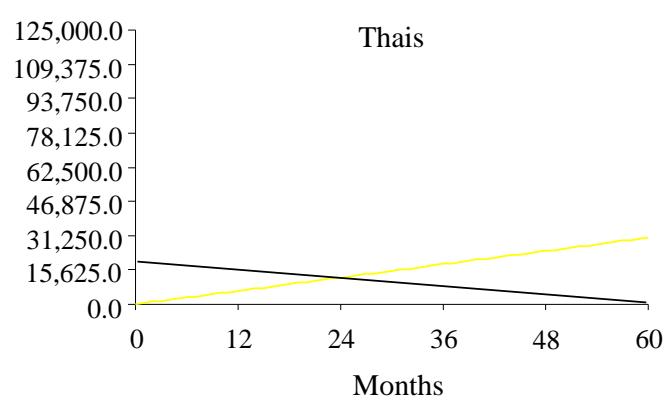

_ Financing balance due

FO - - $\mathrm{BO}-\mathrm{CO}$

Fig 1. Time necessary to pay off the bank financing and cumulative revenues in the period of 60 months. A - mineral nutrient solutions and B - modified nutrient solutions; FM, BM, UM and CM are the mineral solutions of Furlani (1995), Bernardes (1997), Ueda (1990), and Castellane and Araújo (1994), respectively; FO, BO and CO are the modified solutions of Furlani (1995), Bernardes (1997), Castellane and Araújo (1994), respectively.

Table 5. Mean weight of curly lettuce cultivars produced with the mineral nutrient solutions of Furlani (1995) (FM), Bernardes (1997) (BM), Ueda (1990) (UM) and Castellane and Araújo (1994) (CM) and modified nutrient solutions of Furlani (1995) (FO), Bernardes (BO), Ueda (1990) (UO), and Castellane and Araújo (1994) (CO)

\begin{tabular}{|c|c|c|c|c|c|c|c|c|}
\hline \multirow{3}{*}{ Cultivars } & \multicolumn{8}{|c|}{ Nutrient Solutions } \\
\hline & FM & FO & BM & BO & UM & UO & $\mathrm{CM}$ & $\mathrm{CO}$ \\
\hline & \multicolumn{8}{|c|}{ 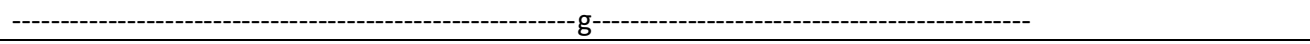 } \\
\hline Verônica & 197.19 & 110.1 & 239.51 & 80.48 & 95.61 & 36.76 & 147.19 & 83.79 \\
\hline Vanda & 179.43 & 72.49 & 216.23 & 80.41 & 102.81 & 46.51 & 145.42 & 62.41 \\
\hline Thaís & 193.97 & 83.92 & 214.71 & 72.34 & 126.49 & 37.4 & 144.74 & 62.23 \\
\hline
\end{tabular}


economic viability of installing a hydroponic system for lettuce production, suggested minimum profits equivalent to those provided by the fixed income financial investments, such as bank deposit certificates (BDC).

The rates usually vary along the year. Therefore, for practical purposes, this simulation assumed a minimum attractive rate of return equal to $12 \%$ per year. The results obtained in the present study are promising because, with the utilization of the mineral solutions, only the cultivar Verônica with the solution UM did not show profitability higher than $12 \%$ per year. For the modified solutions, only Verônica with solution FO led to good profitability, whose value was $36.62 \%$ per year. In the treatments Verônica with CO, Vanda with FO and BO and Thaís with FO, the profitability indices were lower than $12 \%$ per year, which would make the investment little attractive (Table 2). In cases in which there was economic unviability with negative profitability indices, planting was performed with the following combinations: Verônica with solution UO, Vanda with solutions $\mathrm{UO}$ and $\mathrm{CO}$, and Thaís subjected to the solutions $\mathrm{BO}, \mathrm{UO}$ and $\mathrm{CO}$, since the consumer market would pay only 0.14 US\$ plant ${ }^{-1}$, cases in which the gross revenue would be sufficient only to cover the effective operating costs and, therefore, would not have possibility of remuneration for the producer, becoming an unviable investment.

In general, prices of vegetables vary along the year because they are defined according to the quality of the product, which in turn is directly influenced by the climatic conditions. Hydroponic cultivation may provide to the producers higher profitability because of the differentiation of the product, since the sanitary and nutritional quality, besides the visual aspect of hydroponic products, can add higher value to the product for the consumer (Olshe et al., 2001; Souza et al., 2008).

According to a research conducted by Potrich et al. (2012) in Frederico Westphalen, Rio Grande do Sul, $94.4 \%$ of the respondents would pay between US\$ 0.156 and US\$ 0.313 more for the unit of hydroponic lettuce, due to its visual aspect and lower contamination by pesticides. Andrade and Silva (2010) also found the possibility of hydroponic lettuce obtaining better prices compared with the conventional cultivation. In the study conducted in the region of Uberaba, MG, these authors concluded that $61.29 \%$ of the consumers are willing to pay US\$ 0.31 more for the hydroponic lettuce. The break-even point of the activity, in order not to cause economic loss, is obtained when the gross revenue (GR) is equal to the total production cost (TPC). According to Table 2 , in treatments in which the break-even point of the totalproduction cost (BEPTPC) was higher than 100,000.00 units year ${ }^{-1}$, the enterprise would become unviable for having a necessity of production above the projected annual capacity. A similar situation was reported by Geisenhoff et al. (2010), evaluating the economic viability of hydroponic lettuce production in Lavras, MG, Brazil. These authors proposed an increase of $2.13 \%$ in the production, changing from $6,000.00$ to $6,128.00$ units year $^{-1}$ for the total revenue to cover all the total production costs of the activity.

Studies related to the economic viability of hydroponics with the use of organomineral solutions are rare. Most reports found and that evaluate the possibility of financial success with the utilization of hydroponics take into consideration the use of conventional nutrient solutions. Costa (2001) observed a profitability of $71.87 \%$, studying the economic viability of hydroponic lettuce in the periods of autumn and winter in the city of Campinas, São Paulo. Borges and Dal'Sotto (2014), in a study on the economic viability to install a hydroponic cultivation system in a rural property in Western Paraná, found profitability of $20.70 \%$ per year.

According to Table 3, from the fifth year of the activity on, there was a reduction in the production costs with the financing pay off and an increment in the profitability index for all cultivars, regardless of the solution used. However, the solutions that would show the best economic return would be $\mathrm{FM}$ and $\mathrm{BM}$, with profitability indices of $59.63 \%$ and $59.22 \%$, respectively. The increase in profitability in the medium term is a positive factor for the hydroponic activity. The data obtained in the present study corroborate those of Silva and Schwonka (2001), who studied the economic viability of lettuce production in hydroponic system and concluded that, despite the high initial cost, the investments can be converted into benefits in the medium term.

If all the profits obtained in the activity were used to pay off the debt, in only 9 months the financing would be paid off through the commercialization of the lettuce cultivars Verônica, Vanda and Thaís, cultivated in mineral solutions of FM and BM. The cultivars Verônica with the solutions FO and $\mathrm{CM}$, and Vanda and Thaís with $\mathrm{UM}$ and $\mathrm{CM}$, would require 12 and 13 months, respectively. For the cultivars Verônica with $\mathrm{BO}, \mathrm{UM}$ and $\mathrm{CO}$, Vanda with $\mathrm{FO}$ and $\mathrm{BO}$, and Thaís with FO, this time would change to 23 months (Fig. 1A and $1 \mathrm{~B})$.

The possibility of paying off the financing before the deadline stipulated by the financing agent is a suitable information because it reflects the liquidity of the activity. Silva and Schwonka (2001) concluded that the payment of the financing for lettuce hydroponic cultivation, with half of the obtained profit, would occur in 30 months.

Fig. $1 \mathrm{~A}$ and $1 \mathrm{~B}$ also shows that, after paying off the financing, the activity would generate enough resources to expand or install new projects. Using as an example the revenue generated with the utilization of the solutions FM and $\mathrm{BM}$, regardless of the cultivar, the amount of resources accumulated in 4 years and 3 months would be approximately US\$ 97,185.50; already discounted the payment of all costs, including the monthly value of US\$ 656.25 , for business remuneration (producer).

\section{Materials and Methods}

\section{Experiment location and conduction}

The economic viability of curly lettuce hydroponic cultivation was evaluated through a simulation, based on the study on crop production using different mineral and organomineral nutrient solutions.

The experiment was carried out in a hydroponic system, adopting the nutrient film technique (NFT), in a protected environment (greenhouse), at the Center of Agricultural and Environmental Sciences (CCAA) of the State University of Paraíba (UEPB), situated in the city of Lagoa Seca, Paraíba, Brazil, at the following geographic coordinates: $7^{\circ} 10^{\prime} 15^{\prime \prime} \mathrm{S}$, $35^{\circ} 51^{\prime} 14^{\prime \prime} \mathrm{W}$. According to the Köppen-Geige's climatic classification (Brasil, 1971), the climate of the municipality is characterized as humid tropical $\left(A s^{\prime}\right)$, with mean annual temperature around $22 \stackrel{\circ}{\circ}$, minimum of $18 \stackrel{\circ}{\circ}$ and maximum 
of $33 \stackrel{\circ}{\circ}$. The mean temperature in the greenhouse was 35.2 oC.

The experimental design was randomized blocks with split plots and three replicates. Plots consisted of eight nutrient solutions: four mineral solutions, with chemical compositions proposed by Bernardes (1997), Castellane and Araújo (1994), Furlani (1995) and Ueda (1990), which were represented by BM, CM, FM and UM respectively, and four solutions with chemical compositions similar to those previously cited, but modified in the present research with the utilization of biofertilizer in the composition, to produce four organomineral nutrient solutions, which were referred to as modified nutrient solutions of Bernardes (1997) (BO), Castellane and Araujo (1994) (CO), Furlani (1995) (FO) and Ueda (1990) (UO). The subplots were formed by three curly lettuce cultivars, namely: Verônica, Vanda and Thaís. Each plot had two gutters spaced by $0.30 \mathrm{~m}$, through which nutrient solution flowed, and each gutter had 9 curly lettuce plants ( 3 plants of each cultivar) spaced by $0.30 \mathrm{~m}$. The chemical composition of the mineral solutions is described in Supplementary Table 1.

\section{Preparation of the nutrient solutions}

The modified solutions were prepared by initially formulating four biofertilizers with the SOLVER tool of Microsoft Office Excel, to obtain a mixture of organic ingredients with chemical composition similar to those suggested by Ueda (1990), Castellane and Araújo (1994), Furlani (1995) and Bernardes (1997); these biofertilizers were called $\mathrm{BIO} 1, \mathrm{BIO} 2, \mathrm{BIO} 3$ and $\mathrm{BIO} 4$, respectively. The utilized ingredients were bovine manure, bovine milk and poultry blood from the CCAA/UEPB and molasses purchased in the market of Campina Grande, Paraíba. The chemical characterization and quantities of the ingredients used in the preparation of these biofertilizers are presented in Supplementary Tables 2 and 3, respectively.

After formulation, the ingredients were mixed and diluted in $30 \mathrm{~L}$ of tank water (rainwater), undergoing aerobic fermentation for 30 days with the aid of an air compressor, which ensured a dissolved oxygen concentration close to 2.0 $\mathrm{mg} \mathrm{L} \mathrm{L}^{-1}$ and, consequently, the action of aerobic microorganisms. Once matured, samples of the biofertilizers were collected and chemically characterized based on the dry weight, in the Laboratory of Soil, Water and Plant Analysis of the Agricultural Research Company of Rio Grande do Norte - EMPARN. The results are described in Supplementary Table 4.

Since the chemical characterization of the biofertilizers showed nutritional concentration lower than those recommended by Ueda (1990), Castellane and Araújo (1994), Furlani (1995) and Bernardes (1997) (Supplementary Table 1), these biofertilizers needed to be complemented with mineral fertilizers. The quantities of the mineral biofertilizers used to prepare $360 \mathrm{~L}$ of mineral and modified stock solutions are presented in Supplementary Table 5.

\section{Calibration of the nutrient solutions}

The nutrient solutions supplying the gutters were daily calibrated through the addition of tank water and stock nutrient solution according to the treatments, to maintain the volume of $17 \mathrm{~L}$ in the tank, electrical conductivity of 1.5 $\mathrm{dS} \mathrm{m}^{-1}$ and $\mathrm{pH}$ close to neutrality, using a solution of $\mathrm{NaOH}$ or $\mathrm{H}_{2} \mathrm{SO}_{4}\left(1 \mathrm{~mol} \mathrm{~L} \mathrm{~L}^{-1}\right)$. Supplementary Table 6 shows the volumes of supply water and stock nutrient solutions daily replenished during the twenty-four days after transplanting, period that comprehended the experiment.

\section{Economic viability}

\section{Production costs}

Production cost analysis was performed according to the methodology suggested by Martin et al. (1998), which aims to reunite the components of costs aggregating them to allow a detailed analysis of them and of profitability.

The following costs were considered:

- Effective operating cost (EOC): corresponding to the sum of fixed costs (greenhouse and its depreciation) and variable costs (seeds, electric power, maintenance, labor and nutrient solution). The greenhouse corresponds to an area of $850 \mathrm{~m}^{2}$ and to an estimated production of 110,000 plants year $^{-1}$; however, for calculation purposes, a commercial production (well-formed plants with no signs of burn or bolting) of 100,000 plants year ${ }^{-1}$ was considered.

\section{Depreciation of the greenhouse and equipment}

Through the linear method, the annual depreciation rate was calculated by dividing the initial cost (purchase price or replacement price) minus a presumed final scrap value by the number of years of probable duration.

In any year, the depreciation is:

$$
\mathrm{D}=\frac{\mathrm{Vi}-\mathrm{Vf}}{\mathrm{N}}(1)
$$

where:

D - Value of depreciation per year;

Vi - initial value, in US\$;

Vf - final value, in US\$; and,

$\mathrm{N}$ - useful life, in years.

A bank financing value of $\mathrm{R} \$$ US\$ $18,750.00$ was considered for the purchase of the greenhouse and the equipment necessary for its operation. The final value of the structure was stipulated at $10 \%$ of the initial value and the useful life of the system was considered to be 10 years.

Besides depreciation, the analysis also took into consideration the maintenance necessary to keep equipment and facilities in full use condition. To cover the expenditures, a percentage of $4 \%$ on the total invested value was stipulated.

- Total operating cost (TOC): is the effective operating cost plus the social charges ( $36 \%$ on the value of labor expense), contribution to rural social security, CRSS $(2.2 \%$ of the gross income value).

This item also considered a business remuneration necessary to cover the basic expenses of the producer in each year. This remuneration was US\$ 8,156.25 year ${ }^{-1}$.

- Total production cost (TPC): is the total operating cost plus the expenses with land lease (US\$ 406.25 year $^{-1}$ ).

\section{Profitability indicators}

The following indicators of analysis of results were used: a) Gross Revenue (GR): is the expected revenue for a certain production, aiming at a pre-defined or effectively received selling price: 
$\mathrm{GR}=\mathrm{P} * \mathrm{Pu}$

where:

$\mathrm{P}$ - production of the activity; and,

$\mathrm{Pu}$ - unit price of the product of the activity.

b) Gross margin (GMEOC): is the margin in relation to the effective operating cost (EOC), i.e., the result occurred after the producer pays off the effective operating cost, considering a certain unit selling price and the return of the production system for the activity.

Formalized, it is:

$\operatorname{GMEOC}(\%)=((\mathrm{GR}-\mathrm{EOC}) / \mathrm{EOC}) * 100$

where:

GMEOC - gross margin in relation to the EOC;

GR - gross revenue; and,

EOC - effective operating cost.

c) Gross Margin (GMTOC): is defined in a similar way to the gross margin (EOC) for the Total operating cost (TOC), estimated as:

GMTOC $(\%)=((G R-T O C) / T O C) * 100$

where:

GMTOC (\%) - gross margin in relation to the TOC; and, TOC - Total operating cost.

Thus, this margin indicates which is the availability to cover, besides the effective costs, the social charges and business remuneration (owner).

d) Gross Margin (GMTPC): is the margin in relation to the total production cost (TPC), i.e., the result occurred after the producer pays all costs off, considering a certain unit selling price and the return of the production system for the activity, calculated as:

$\operatorname{GMTPC}(\%)=((\mathrm{GR}-\mathrm{TPC}) / \mathrm{TPC}) * 100$

Where:

GMTPC (\%) - gross margin in relation to the TPC; and, TPC - total production cost.

e) Break-even points: are indicators of cost in relation to the units of product, referred to BEP, which determine which is the minimum production necessary to cover the cost, considering the unit selling price for the product. Thus, the following break-even points were considered:

$\begin{array}{lll}\text { BEPEOC } & = & \text { EOC } / \mathrm{Pu} \\ (6) & & \\ \text { BEPTOC } & \mathrm{TOC} / \mathrm{Pu} \\ (7) & \mathrm{TPC} / \mathrm{Pu} \\ \mathrm{BEPTPC} & = & \\ (8) & & \end{array}$

f) Operating profit (OP): is the difference between the gross revenue and the Total operating cost (TOC) per year:

$\mathrm{OP}=\mathrm{GR}-\mathrm{TOC}$
The operating profit (OP) measures the profitability of the activity in the short term, showing its financial and operational conditions.

g) Profitability Index (PI): this indicator shows the relationship between the operating profit (OP) and gross revenue (GR), in percentage. It is an important measure of profitability of the agricultural activity, because it shows the available revenue of the activity after the payment of all operating costs, charges etc., including depreciations. It is obtained as follows:

$\mathrm{PI}=(\mathrm{OP} / \mathrm{GR}) * 100$

This simulation considered an initial investment of $\mathrm{R} \$$ $60,000.00$, obtained by the producer in a financial institution with interest rate of $6.5 \%$ a year (Brasil, 2014). The prediction to pay off the balance due was 5 years, with annual installments of US\$ $4,402.38$

The unit selling price of the lettuce was stipulated by correlating the mean weight of the lettuce produced in this study (Table 5) with those commercialized in the main supermarkets of the municipality of Campina Grande, Paraíba, according to the following criterion:

Plants with weight lower than $75 \mathrm{~g}=$ US\$ 0.14;

Plants with weight between 75 and $100 \mathrm{~g}=$ US\$ 0.23;

Plants with weight between 101 and $150 \mathrm{~g}=$ US\$ 0.31; and, Plants with weight higher than $150 \mathrm{~g}=$ US\$0.39.

\section{Conclusion}

The hydroponic cultivation of lettuce proved to be an economically profitable activity. According to the simulation, the time to pay off the loan varied depending on the utilized nutrient solutions, and the use of modified nutrient solutions of Castellane and Araújo (1994), Bernardes (1997) and Ueda (1990) was unviable. The mineral nutrient solutions of Bernardes (1997) and Furlani (1995) promoted the best economic returns, regardless of the tested cultivar. The cultivar Verônica subjected to the modified nutrient solution of Furlani (1995) was economically profitable.

\section{Acknowledgments}

The authors thank the State University of Paraíba, for its contribution through the PROPESQ program to conduct this research.

\section{References}

Andrade MPR, Silva ARP (2010) Marketing do Comportamento do consumidor e da comercialização da alface hidropônica. Trabalho apresentado no 5 a Congresso Norte Nordeste de Pesquisa e Inovação, Instituto Federal de Alagoas, Maceió, 17-19 de Novembro de 2010.

Andriolo JL, Luz GL, Bortolotto OC, Godoi RS (2005) Produtividade e qualidade de frutos de meloeiro cultivado em substrato com três doses de solução nutritiva. Ciên. Rural. 35: 781-787.

Bernardes LJH (1997) Hidroponia da alface: uma história de sucesso. São Paulo: Estação Experimental de Hidroponia "Alface e Cia". 
Borges R, Dal'Sotto TC (2014) Estudo da viabilidade econômica de um sistema de cultivo hidropônico. Trabalho apresentado no 4 o Congresso Brasileiro de Engenharia de Produção, Universidade Federal Tecnológica do Paraná. Ponta Grossa, 3-5 de dezembro de 2014.

Brasil (2014) Banco Central do Brasil, credito rural. Disponível em: http://www.bcb.gov.br/?creditoruralfaq. Acesso em 15 dez. 2014.

Brasil (1971) Ministério da Agricultura. Equipe de Pedologia e Fertilidade do Solo. Levantamento exploratório. Reconhecimento de solos do estado da Paraíba. Rio de Janeiro, SUDENE, 670p. (Boletim Técnico, 15).

Castellane PD, Araújo JAC (1994) Cultivo sem solo: hidroponia Jaboticabal, FUNEP.

Cometti NN, Matias GCS, Zonta E, Mary W, Fernandes MS (2008) Efeito da concentração da solução nutritiva no crescimento da alface em cultivo hidropônico-sistema NFT. Hortc Bras. 26: 252-257.

Costa CP, Sala FC (2012) A Retrospectiva e tendência da alfacicultura brasileira. Hortc Bras. 30: 187-194.

Costa, E. (2001) Avaliação da produção de alface em função dos parâmetros climáticos em casas de vegetação com sistema hidropônico nos períodos de outono e inverno. 144f. Dissertação (Mestrado em Engenharia Agrícola). Universidade Estadual de Campinas (UNICAMPI), Campinas, São Paulo.

Fernandes JD, Monteiro Filho AF, Chaves LHG, Gonçalves CP, Cruz MP (2011) Formulação de biofertilizante utilizando a ferramenta Solver do Microsoft Office. Rev Verde Agroecol Desenv Sustenta. 6: 101-105.

Furlani PR (1995) Cultivo de alface pela técnica de hidroponia - NFT. Campinas: IAC, 18p. (IAC Documentos 55).

Geisenhoff LO, Pereira GM, Faria LC, Júnior JAL, Costa GG, Gatto RF (2010) Viabilidade econômica da produção de alface hidropônica em Lavras - MG. Agrarian. 2: 61-69.

Henz GP, Suinaga $F$ (2009) Tipos de alface cultivados no Brasil. Brasilia: Embrapa hortaliças, 7p (Embrapa hortaliças, Comunicado Técnico 75).

Ibge (2009) - Instituto Brasileiro de Geografia e Estatística Censo Agropecuário 2006. Rio de Janeiro.
Martin NB, Serra R, Oliveira MDM, Ângelo JA, Okawa H (1998) Sistema integrado de custos agropecuários. Infor Econ. 28: 7-28.

Martinez HEP, Silva Filho JB (2006) Introdução ao cultivo hidropônico de plantas. Viçosa, UFV.

Olshe S, Dourado-Neto D, Manfron PA, Santos OS (2001) Qualidade de cultivares de alface produzidos em hidroponia. Sci Agri. 58: 181-185.

Potrich ACG, Pinheiro RR, Schmidt D. (2012) Alface hidropônica como alternativa de produção de alimentos de forma sustentável. Enci Bios. 8: 36-48.

Rezende R, Helbel Junior C, Freitas PSSL, Gonçalves ACA, Dallacort R, Frizzone JA (2007) Diferentes soluções nutritivas aplicadas em duas vazões na produção hidropônica da cultura da alface. Irriga. 12: 354-363.

Rodrigues, L.R.F. (2002) Técnicas de cultivo hidropônico e de controle ambiental no manejo de pragas, doenças e nutrição vegetal em ambiente protegido. Jaboticabal, Funep.

Santos AO, Neto BLR, Zwirtes DS, Da Silva RB, Yonenaga WH (2008) Produção de alface hidropônica: uma abordagem pela dinâmica de sistemas. Trabalho apresentado no 40 Congresso Brasileiro de Sistemas, Uni-Facet, Franca, 29-30 de Outubro de 2008.

Silva ET, Schwonka F (2001) Viabilidade econômica para a produção de alface no sistema hidropônico em Colombo, região metropolitana de Curitiba, PR. Sci Agra. 2: 126-132. Soares I. (2002) Alface: cultivo hidropônico. Fortaleza, UFC.

Souza IRS, Arbage AP, Neumann OS, Diesel JMFV, Silveira PR, Silva A, Baumhardt, CCE, Lisboa RS (2008) Comportamento de compra dos consumidores de frutas, legumes e verduras na região central do Rio Grande do Sul. Ciên Rural. 38: 511-517.

Ueda S (1990) Hidroponia: guia prático. São Paulo, Agroestufa,

Villela Júnior LVE, Araújo JAC, Factor TL (2004) Análise do resfriamento da solução nutritiva para cultivo hidropônico do morangueiro. Eng Agrí. 24: 338-346. 